\title{
Building Goodwill through Soft Power: An Analysis of China's Reputation in Sri Lanka
}

\author{
Rajapakshe Devalage Pathmasiri Sampath Rajapakshe ${ }^{1}$ \\ ${ }^{1}$ Department of Economics, University of Kelaniya, Sri Lanka \\ Correspondence: R. D. P. Sampath Rajapakshe, Department of Economics, University of Kelaniya, Kelaniya, Sri \\ Lanka. E-mail: sampath367@yahoo.com
}

Received: January 20, 2016

Accepted: February 7, 2016 Online Published: February 28, 2016

doi:10.5539/jpl.v9n1p48

URL: http://dx.doi.org/10.5539/jpl.v9n1p48

\begin{abstract}
Many researchers find out that impacted the types of Chinese foreign policy starting in the mid-1990s. However, Chinese foreign policymakers presented "New Grand Strategy" for the 21st century in the mid-1990s. This strategy exceptionally intended to advance and keep up China's image in the abroad. On the other hand, Policy observers contend introducing of the South Asian region that deliberately essential to emerging China. In addition, Chinese vicinity in Sri Lanka that verbalized by policy observers numerous ways. These contentions express that China's soft power in Sri Lanka that ought to be an extraordinary choice in Chinese policy arrangement. This article investigates current appearance of China's goodwill agenda inspecting two strains of Chinese policy in Sri Lanka that breaking point to observe foreign aid and the Confucius institute that lead the Peoples' Republic of China in 2000s. The paper additionally assesses the achievement of this alleged soft power crusade in Sri Lanka utilizing a worldwide overview to figure out whether the new introduction associates with changed Sri Lankan conclusions about China. This article assesses the adequacy of these endeavors by breaking down public opinion survey accumulated by the Gallup surveying in 2011. Information utilized for this article has been gathered from a substantial number of books, periodicals, magazines, journals. My findings demonstrate that the goodwill agenda has been fruitful at enhancing China's reputation in Sri Lanka.
\end{abstract}

Keywords: goodwill, soft power, public opinion, reputation

\section{Introduction}

Many researchers find out that impacted the types of Chinese foreign policy starting in the mid-1990s. On the other hand, Chinese foreign policy makers presented "New Grand Strategy" for the 21st century in the mid-1990s. This strategy uniquely intended to advance and keep up China's image in the abroad. The goodwill motivation can be seen as a soft power campaign that incorporate cultural, institution and aid related strategies. Goodwill upsurges nation's image, reputation and influence in the across the world.

On the other hand, Policy observers argue presenting of the South Asian region that deliberately critical to emerging China. In addition, Chinese vicinity in Sri Lanka that enunciated by policy observers numerous ways. These contentions express that China's soft power in Sri Lanka that ought to be an extraordinary choice in Chinese foreign policy.

This article investigates current appearance of China's goodwill agenda analyzing two strains of Chinese current foreign policy in Sri Lanka that utmost to observe foreign aid and culture that offered to Sri Lanka by the Peoples' Republic of China in 2000-2011. The paper likewise assesses the accomplishment of this supposed soft power campaign in Sri Lanka utilizing an international survey to determine whether the new introduction connects with changed global sentiments about China. This article assesses the viability of these endeavors by analyzing public opinion polls accumulated by the Gallup polling survey in 2011. Additionally here examine when and why have attitudes of Sri Lankans towards China progressed.

\subsection{Soft Power and International Relations}

According to international relations theories and debates, soft power is a modern concept which aims to raise awareness of the political dimension through cultural actions. In the international politics soft power is established to a great extent in a nation's values communicated through its culture in taking care of its relations with different states. For instance, subsequent to being vanquished in the Franco-Prussian war, France 
endeavored to restore his reputation by advancing their cultural instruments through the Alliance (Melissen, 2005). In like manner, the extension of their culture in international society turned into an imperative segment of diplomacy in that nation. With a specific end goal to accomplish more compelling endeavors abroad, the decision makers of different states now investigate and execute new activities under the alleged soft power to accomplish their foreign policy destinations.

Today, with the advancement of the processes of economic and technological globalization, international relations will depend always seriously on culture, (or soft power) and economic power as opposed to military power. Albeit both hard power (political, economic and military activity) and soft power are important instruments to direct the foreign policy interests of one nation, the activity of fascination (Soft power) is much less expensive than coercion, or more all is of a higher worth. A nation needs to be a powerful nation that needs hard power and in addition goodwill to pick up adaptability inside of international politics. A world power ought to appear as a world cultural center including thoughts, values, norms; social life and convictions are alluring and speaking to individuals of rest of the world. Soft power does not make consequently affected by hard power; it must be deliberately enhanced and set up (Melissen, 2005).

\section{Method and Materials}

I measure the level of China's foreign aid in Sri Lanka by analyzing the number of completed aid projects from 2005-2012, documented by the External Resource Department of the Ministry of Finance and Planning in Sri Lanka. Data collection from a large number of book, periodicals, magazines, journals, world wide Web and results of the Gallup public opinion in 2008, 2009, 2010 and 2011. The descriptive analysis use to evaluate the success of China's soft power in Sri Lanka, multiple dimensions from 2005 to 2012.

\section{Results and Findings}

South Asia is relentlessly developing as a key need for the PR and Sri Lanka situated that strategically place in the Indian Ocean. Recently, Chinese leaders had talked about the policy preferences of the current administration. They said; "Tranquil improvement is Chinas fundamental state policy, and win -win collaboration is flag for China's well-disposed relations with different nations. To understand "China's dream", we should have a serene worldwide environment. In the meantime, the nation will unfalteringly shield its national sway, security and interests. The two policy arrangements are two mainstays of Chinese tact, and don't struggle with each other" (Fernando, 2011).

China's strategy recognition would decipher as enthusiastically shielding the integrity of her territorials, seeking after PRC's regional cases, creating key correspondence lines to the border areas. India is becoming a rising power dominating the Indian Ocean this adds to China's key concerns. PRC's uncertain territorial debate and unfulfilled regional cases with India have continued stewing honorably as India's developing key association with the US and Japan (Thomas, 2012).

India is getting to be as an overwhelming power in the Indian Ocean that pertinence to include Chinese soft power in Sri Lanka. China and India couldn't determine their inter-state dispute, for example, border conflicts. Then again, India's developing association with United States and Japan. In any case, China seems to have understood the need to keep away from head-on showdown with India and build a win-win relationship exploiting one another's economic qualities. China's growing soft power in Sri Lanka that prone to affect the US and Western powers too. Moreover, Chinese soft power in Sri Lanka that can articulate many ways in policy perspectives. The emergence of China as a global power center the geographic position of Sri Lanka is important to Chinese vital trade routes in Indian Ocean that has marked approximately to Sri Lanka. Secondly, China's engagement in is a tit-for-tat strategy in response to India's relations with China's South Asian peripheral. Thirdly, it's related to China's "String of Pearls" strategy establishing.

Considering this environment, constructing a strong association with Sri Lanka was an intelligent stride for China as it centers an indispensable ideal position in securing her national interests in the Indian Ocean while giving a key turn in the Under belly of India. Sri Lanka can have a gigantic impact in India's vital security because of its geographic closeness to India. Regardless, smallness makes it moves helpless against India's vital moves (Elmie, 2010). This is relevant to the rising part of China in Sri Lanka.

Chinese culture provides the premise to one of the nation's solid resources and has appealed to foreigners all through history. Nye contends that culture assumes an imperative part in a nation's soft power, and it is in this way obvious that cultural strategies highlight conspicuously in China's Goodwill Agenda. Culture conveys the power of fascination and in his productive written work on American soft power; Nye reliably indicates Hollywood, educational exchanges, popular sports, CNN and other cultural strengths that offer the United States 
some assistance with achieving its foreign policy objectives and represent to a persisting element of American soft power. Many countries, including China and United States support language institutions, student exchanges or cultural projects to improve their national personality. The Confucius institute project is an outgrowth of Chinese endeavors in this enclosure. Intended to spread enthusiasm for Chinese culture, advance international business action inside of China and increase the number of people studying Chinese language, Confucius institutes and classrooms are an endeavor to highlight to positive components of China's image.

In Sri Lanka, the Chinese goodwill agenda can be seen as a soft power campaign that consolidates cultural, institutional and aid related strategies with a specific end goal to support the Chinese image and impact. The Confucius Institute at the University of Kelaniya in Sri Lanka is representation of preparing that basically, progression of the Chinese mandarin, being used as a gadget for building goodwill. China Radio International (CRI) - China's state-possessed abroad supporter is driving on-air Confucius Institute in Sri Lanka. The social discretionary exercises have been executed through the Chinese instructive grants. Beijing has been putting forth grants to Sri Lankans for concentrating on Chinese dialect furthermore looking for after changed studies and scrutinize in China. The China Scholarship Council (CSC) has an update of comprehension (MOU) with the Higher Education Ministry of Sri Lanka, while China recompenses around 23 grants to Sri Lanka every year (The Government Information, 2014). Through these exercises, China has had the ability to propel itself as an inside for higher learning in solution, science and Technology. This is a portion of China's goodwill is detectable in Sri Lanka.

China has begun a couple of understandings for empowering goodwill with individual South Asian countries. Social exchanges among China and Sri Lanka were empowered through an institutional understanding marked in August 1979 (Elmie, 2010). Beside these formal understandings among China and Sri Lanka, there are normal visits, and social exchange programs between two countries.

The Confucius Institute undertaking is not simply social technique of China's goodwill plan. China has viably used conspicuous events, for instance, the 2008 Beijing Olympics and the 2010 Shanghai World Expo to showcase Chinese progression, history and social beliefs.

Notwithstanding, the Confucius institute venture speaks to China's most vital strategy along the cultural front and the Chinese government helps fund and encourage the program. After European language and cultural institute, for example, American Cultural Center and British Council, Confucius institute project extend comparatively endeavors to advance language and culture for diplomatic proposes in Sri Lanka. The Confucius institute in Sri Lanka highlights just positive components of the China brand produces enthusiasm for the nation; the general undertaking can be viewed as a sort of impression administration that underscored the picture of "a kinder and gentler China". Thusly, the Confucius institute project in Sri Lanka represents a solid case of a cultural soft power in China's universal reputation.

\section{Discussion}

From this connection, China's goodwill agenda can be seen as a soft power campaign intended to support the nation's general global impact and respond to thereat oriented images about China. Joseph Nye noticed the term 'soft power' in 1990, which he portrays as the capacity to get what you need through fascination as opposed to pressure or installments (Nye, 2004). Unmistakable from more customary understandings of military and economic power, soft power provides a nation extra base of power, one with the capacity to get "others to want the outcomes that you want" without applying huge assets or strong arm strategies to accomplish your objectives (Nye, 2004).

In this way, on the off chance that we consider soft power as alluring power, China's Goodwill Agenda is unmistakably intended to make China all the more speaking to international audiences. It attempts to advance a benign, positive, and peaceful image of China around the world through cultural, institutional and aid related strategies. Goodwill needs to offer China some assistance with winning companions and allies, and to progress to nation's agenda.

China foreign aid program structure one of the vital strains of the goodwill agenda. Like all other donor countries, China offers aid for various reasons such as political, economic and ideological; China is gives aid as well as different nations to utilize aid to improve goodwill. China's aid projects is rhetoric and practice that taking into account peaceful co-existence principle, particularly, non-interference in domestic issues that a typical policy Sri Lanka as sovereign nation.

Understanding of two countries have been happening more grounded in the course of recent years; particularly as western governments started making so as to cut aid domestic issues on minority rights in Sri Lanka. In this 
connection, China decided that it released one million US dollars to conduct the reconciliation and rehabilitation process in war affected areas in Sri Lanka. China's acquisitions of 20 million Yuan tents have in like manner come to Sri Lanka. China extended its assistance to Sri Lanka from a few million dollars in 2005 to around one million US dollar in 2008. By 2011, the total whole of advancement aid got from China surpassed the total assistance by Japan, Traditionally, the main supplier of foreign assistance for Sri Lanka (Amarasjnghe, 2013). The measurements of foreign assistance from China amid 1971-2012 stands at US\$ 5.056 million, of which 94\% was given in the midst of the latest eight years. Chinese responsibilities have climbed from $3 \%$ of all foreign aid in 2002 to $32 \%$ in 2012, going to a top of 38\% in 2011 (Amarasinghe, 2013).

On thirteenth August 2009 Sri Lanka marked two key developmental errands specifically Colombo Katunayake express path and in addition Hambantota bunkering venture that lactated southern part of Sri Lanka worth US 350 million dollars with the Exim Bank of China (Foreign Aid Review, 2009). These projects will influence the future financial improvement in Sri Lanka.

PRC gave special assistance taking after the natural disaster in Sri Lanka. Chinese government offered US 1.5 million dollars in financial backing and alleviation merchandise (Amarasinghe, 2013). China likewise embraced remaking ventures in tidal wave influenced territories, for cases, China-Sri Lanka relationship town; China-Sri Lanka Red Cross town and reproduction work in three fisheries harbors. The Sri Lankan government started revamping of transport section and China has given latest railroad motors and control sets moreover hundred traveler carriages. Chinese helps have been used particularly for national's needs basically streets and spans, electricity and transportation. In actualizing these tasks that included Chinese leading companies, such as the metallurgical cooperation, the China Harbor designing organization, the Sin-hydro Cooperation, the China National Group Cooperation. (Amarashinghe, 2013).

In order to evaluate the effectiveness of these soft power strategies I divide my analysis into two strains of foreign policy which culture and foreign aid. My objective here is to observe China's Goodwill Agenda and decide these strategies absolutely influenced China's reputation in Sri Lanka. I utilize polling data from the Gallup polling survey results which conducts of survey on opinion on Sri Lanka, to assess of these endeavors. This is the line with different researchers Nye and d' Hooghe who use opinion polls to measure the impact of soft power strategies (Nye, 2004). The Goodwill Agenda is intended to build a positive China brand, and I expect that China enhance their general sentiment of China when they keep on sharing foreign policy preferences.

The publically available Gallup opinion polling results as a particularly useful survey because it intended public opinion of Sri Lankans about major power. The question - "Do you affirm or object to the occupation execution of the initiative of China, United States, and United Kingdom...."asked from Sri Lankan adults has been subsequent to 2008-2011. Results depend on thousand vis-à-vis interviews with elder citizens, ages constrained is 15 or more seasoned. For results in light of aggregate specimen of national elders, one can say with $95 \%$ certainty that the most extreme edge of sampling error is \pm 4.1 rate focuses. The margin of error reflects the impact of information weighting. Notwithstanding inspecting error, question wording and practical difficulties in directing reviews can bring mistake predisposition into the discoveries of public opinion surveys. 
Table 1. Goodwill of the major powers in Sri Lanka

\begin{tabular}{|c|c|c|c|c|}
\hline Year & 2008 & 2009 & 2010 & 2011 \\
\hline \multicolumn{5}{|c|}{ People's Republic of China } \\
\hline Approve & $39 \%$ & $36 \%$ & $34 \%$ & $31 \%$ \\
\hline Disapprove & $4 \%$ & $7 \%$ & $7 \%$ & $10 \%$ \\
\hline Don’t know & $57 \%$ & $56 \%$ & $59 \%$ & $60 \%$ \\
\hline \multicolumn{5}{|c|}{ United States of America } \\
\hline Approve & $36 \%$ & $36 \%$ & $30 \%$ & $24 \%$ \\
\hline Disapprove & $12 \%$ & $13 \%$ & $17 \%$ & $26 \%$ \\
\hline Don’t know & $52 \%$ & 51 & $54 \%$ & $51 \%$ \\
\hline \multicolumn{5}{|c|}{ United Kingdom } \\
\hline Approve & $29 \%$ & $21 \%$ & $22 \%$ & $21 \%$ \\
\hline Disapprove & $7 \%$ & $17 \%$ & $15 \%$ & $18 \%$ \\
\hline Don’t know & $64 \%$ & $63 \%$ & $64 \%$ & $62 \%$ \\
\hline \multicolumn{5}{|c|}{ Russia } \\
\hline Approve & $22 \%$ & $21 \%$ & $20 \%$ & $19 \%$ \\
\hline Disapprove & $6 \%$ & $11 \%$ & $11 \%$ & $15 \%$ \\
\hline Don’t know & $72 \%$ & $68 \%$ & $69 \%$ & $66 \%$ \\
\hline \multicolumn{5}{|c|}{ Germany } \\
\hline Approve & $16 \%$ & $16 \%$ & $16 \%$ & $16 \%$ \\
\hline Disapprove & $6 \%$ & $14 \%$ & $12 \%$ & $16 \%$ \\
\hline Don’t know & $78 \%$ & $70 \%$ & $72 \%$ & $78 \%$ \\
\hline
\end{tabular}

Source - http://www.gallup.com/

The table shows more Sri Lankans concur with the performance or leadership of China that of the United States, and they disappoint about some western nations' activity in Sri Lanka. They will probably affirm than dislike China's relations with current government. Sri Lankans are less intrigued with other nations' goodwill, for example, the United States, the United Kingdom, Germany, Russia, albeit numerous don't know enough about them to offer a sentiment. U.S. performance, which has been one of the more vocal faultfinders of the Sri Lankan government's endeavors to investigate the domestic issues in the post-conflict situation, has lost favor. Twenty-four percent of Sri Lankans say they favor of U.S. activities, down 12 rate focuses from $36 \%$ in 2008 and 2009. 


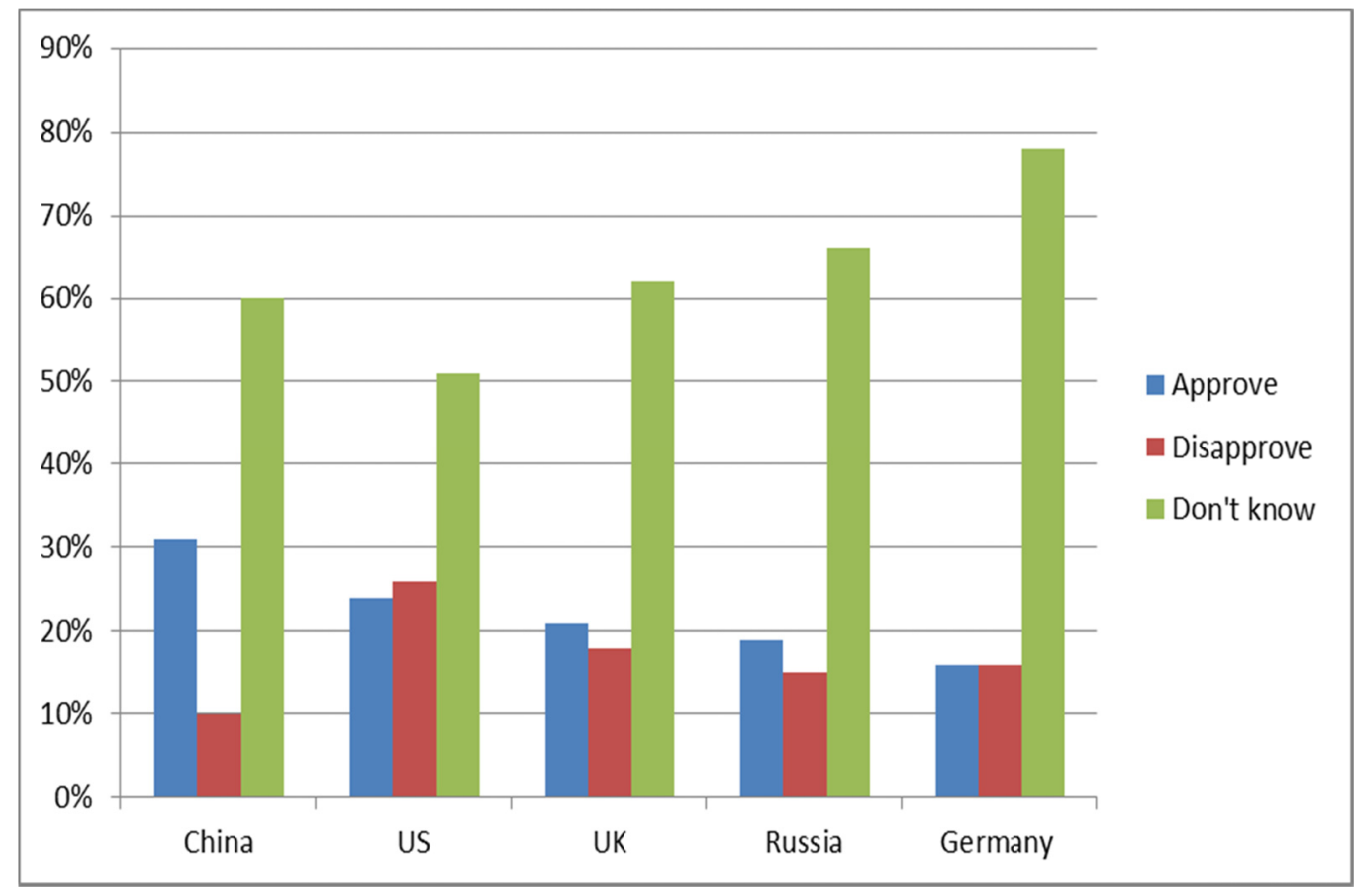

Figure 1. Sri Lankans opinion about the Major Powers in 2011

Source: Gallup Polling Survey Data - 2009

\section{Conclusion}

The developing of PRC reputation in cutting edge Sri Lanka is not a begging to be proven wrong point. The mystery is the quickness and the economy with statistical data points in its aid and cultural relations. The realities remains that China has been a long standing companion of Sri Lanka. As China's economy power has developed contributing abroad has been a strategy utilized over the world by China to support the national interests. China Strategic clout in Sri Lanka is expanding each day. Much Chinese assistance like Colombo container terminal, Hambantota port and Maththala airplane terminal, satellite and telecom attempts give true blue access to develop goodwill. China goodwill is expanding obvious in all parts of Sri Lanka like society, political, diplomatic and development fronts also. Chinese language instructing and social norms spread are likewise on the cards as a Confucius Institute is schedule in Colombo. With regards to Chinese vital goodwill in Sri Lanka, there are a few hypotheses that have been enunciated by foreign policy spectators. Firstly, with the rise of China as a global power center, the geographic position of Sri Lanka is essential to China's fundamental sea routes. Secondly, China's engagement is a tit-for-tat strategy in response to India's engagement in China's own South East Asian backyard. Thirdly, it is contended this is a piece of China's "String of Pearls" procedure setting up Chinese maritime bases in Myanmar, Pakistan, Bangladesh and Sri Lanka; lastly that it is a general signal of goodwill and building political capital in Sri Lanka.

\section{References}

d' Hooghe, I. (2011). The Limits of China's Soft Power in Europe: Beijing's Public Diplomacy Puzzle. New York: Palgrave Macmillan.

Department of External Resources Ministry of Finance and Planning, Sri Lanka. (2009). Foreign Aid Review 2007, 2008 and 2009. Colombo: Government Press.

Dhanusha, A., \& Rebert, J. (2013). Dynamics and Trends of Foreign Aid in Sri Lanka: Exploring space for context-sensitive aid delivery. International Alert.

Elmie, K. R. (2010). Soft Power Game: A Study of China, India and South Asian Association for Regional Cooperation (SAARC) Tripartite. Retrieved March 23, 2015, from indiachinainstitute.org/.../2010/.../Elmie-Soft-Power-Game-A-Study-of-China-India-and-SAARC-Tripartite

Gallup Polling. (2011). Sri Lankans Back Their Leadership Amid Western Criticism: Less approving of U.S. leadership. 
http://www.gallup.com/poll/149306/Sri-Lankans-Back-Leadership-Amid-Western-Criticism.aspx

Joseph, N. (2004). Soft Power: The Means to Success in World Politics. New York: Perseus.

Melissen Jan. (Ed.). (2005). The New Public Diplomacy: Soft Power in International Relations. New York: Palgrave McMillan.

Nye, J. S. (2004). Soft Power: The Means to success in World Politics. New York: Public Affairs.

Sithara, F. N. (2011). China's Relations with Sri Lanka and the Maldives: Among Big and Small Countries Models of Good Relations. Retrieved May 1, 2015, from http://chr.sagepub.com/content/46/3/285

Thomas, L., Morrison, W. M., \& Bruce, V. ( 2008). CRS Report for Congress, China's 'Soft Power' in Southeast Asia. Retrieved June 23, 2015, from https://www.fas.org/sgp/crs/row/RL34310.pdf

\section{Copyrights}

Copyright for this article is retained by the author(s), with first publication rights granted to the journal.

This is an open-access article distributed under the terms and conditions of the Creative Commons Attribution license (http://creativecommons.org/licenses/by/3.0/). 